Article

\title{
Regulation of Transcription Factor E2-2 in Human Plasmacytoid Dendritic Cells by Monocyte-Derived TNF $\alpha$
}

\author{
Hannah K. Dewald ${ }^{1}\left(\mathbb{D}\right.$, Harry J. Hurley ${ }^{1,2}{ }^{\mathbb{D}}$ and Patricia Fitzgerald-Bocarsly ${ }^{1,2, *(D)}$ \\ 1 Rutgers School of Graduate Studies, Newark, NJ 07103, USA; hkd17@gsbs.rutgers.edu (H.K.D.); \\ hjh42@njms.rutgers.edu (H.J.H.) \\ 2 Department of Pathology, Immunology, and Laboratory Medicine, Rutgers New Jersey Medical School, \\ Newark, NJ 07103, USA \\ * Correspondence: bocarsly@njms.rutgers.edu; Tel.: +1-973-972-5233
}

Received: 9 December 2019; Accepted: 26 January 2020; Published: 31 January 2020

\begin{abstract}
Plasmacytoid dendritic cells (pDCs) are innate immune cells and potent producers of interferon alpha (IFN $\alpha$ ). Regulation of $\mathrm{pDCs}$ is crucial for prevention of aberrant IFN production. Transcription factor E2-2 (TCF4) regulates pDC development and function, but mechanisms of E2-2 control have not been investigated. We used freshly-isolated human peripheral blood mononuclear cells stimulated with toll-like receptor 7, 9, and 4 agonists to determine which factors regulate E2-2. After activation, pDCs decreased E2-2 expression. E2-2 downregulation occurred during the upregulation of costimulatory markers, after maximal IFN production. In congruence with previous reports in mice, we found that primary human pDCs that maintained high E2-2 levels produced more IFN, and had less expression of costimulatory markers. Stimulation of purified pDCs did not lead to E2-2 downregulation; therefore, we investigated if cytokine signaling regulates E2-2 expression. We found that tumor necrosis factor alpha (TNF $\alpha$ ) produced by monocytes caused decreased E2-2 expression. All together, we established that primary human pDCs decrease E2-2 in response to TNF $\alpha$ and E2-2 low pDCs produce less IFN but exhibit more costimulatory molecules. Altered expression of E2-2 may represent a mechanism to attenuate IFN production and increase activation of the adaptive immune compartment.
\end{abstract}

Keywords: plasmacytoid dendritic cell; E2-2; TCF4; transcriptional regulation

\section{Introduction}

Identified as the primary type 1 interferon producing cells, plasmacytoid dendritic cells (pDCs) have garnered interest because of their capacity to produce up to 1000-fold more interferon alpha $(\mathrm{IFN} \alpha)$ than any other cell [1-3]. This unique ability gives $\mathrm{pDC}$ a critical role in protection against pathogens [4]. pDCs are innate immune cells that sense viral ssRNA and DNA through toll-like receptors (TLR) 7 and -9, respectively. Stimulation through each of these TLRs converge on the same downstream pathway, ultimately leading to the phosphorylation and translocation of interferon regulatory factor 7 (IRF7) and transcription of Type I IFNs [5,6]. pDC activation is not limited to TLR7 and -9 -they also express functional TLR4 [7]. Previous work in our lab found that pDCs respond to lipopolysaccharide (LPS) through TLR4 by upreg ulating IRF7 and TLR4, ultimately priming pDCs to produce more IFN in response to a secondary viral signal [7].

Development of pDCs begins in the bone marrow, where these cells originate from a common dendritic cell (DC) progenitor and culminates with migration and maturation in the blood and tissue $[2,8]$. The fate of the DC progenitor is dependent on the balance of key developmental factors, 
including ID2, IKZF1, NOTCH1, SPIB, and TCF4 [9-13]. In humans, myeloid dendritic cells (mDCs) diverge from $\mathrm{pDCs}$ at the progenitor stage and mature into one of five different $\mathrm{mDC}$ populations currently identified [8,14]. pDC arise in the presence of FLt3-ligand and IL-3, which activate STAT3. STAT3, in turn promotes the expression of transcription factor E2-2 (TCF4) [11]. E2-2 is required for pDC development $[10,11,15,16]$ and promotes canonical pDC phenotype and function [17].

E2-2 is a basic helix-loop-helix transcription factor that binds the E-box sequence "CANNTG." Binding of E2-2 can either activate or repress target genes [18]. E2-2 is highly expressed in pDCs and at low levels in mDCs and B cells. In pDCs, E2-2 promotes several archetypal $\mathrm{pDC}$ genes, such as SPIB, ILT7 and TLR7/9, and represses mDC-associated genes [4,10,17]. In mice, whole system E2-2 knockout ablates all pDC development $[10,16]$, while inducible knockout of E2-2 in peripheral pDCs causes a conversion to an $\mathrm{mDC}$-like cell with altered phenotype and function [15]. This is marked by expression of $\mathrm{mDC}$ markers CD11c and CD8 and a complementary loss of pDC markers, such as CIITA. Change in phenotype is accompanied by a significant reduction in the capacity for Type 1 IFN production and increased ability to stimulate T cells [15].

Studies of pDCs have indicated that mature pDCs alter E2-2 expression in response to a variety of stimuli $[16,19]$. In vitro, human pDC cell lines that downregulate E2-2 exhibit a similar phenotype and function as described in murine E2-2 knockout pDCs [17]. However, human pDC cell lines do not completely recapitulate the transcriptional and functional profile of primary pDCs [20]. Particularly, they are poor producers of type I IFN and can produce a significant level of interleukin 12 [21-23]. mDCs that display both $\mathrm{pDC}$ and $\mathrm{mDC}$ characteristics and rely on E2-2 for development have been identified in mice, and human tonsils and blood $[8,14,24-26]$. The presence of these cells indicates that there may be a population of DCs that are actually pDCs that downregulated E2-2 in the periphery. In the context of chronic viral infection, we observed that pDCs from HIV-infected donors have decreased expression of E2-2 [27]. pDCs from people living with HIV are both numerically and functionally deficient [reviewed in [28]. Together, these data indicate that E2-2 expression can be altered in result of physiological conditions which may lead to the development of a DC with $\mathrm{pDC}$ and $\mathrm{mDC}$ characteristics.

Until now, the upstream processes that contribute to E2-2 regulation in the context of human pDC activation have remained unstudied. In this investigation, we determined the temporal regulation of E2-2 in response to TLR 7, 9, and 4 stimulation and found that downregulation occurs after 18-24 $\mathrm{h}$ after the start of stimulation. In congruence with previous literature, we confirmed that pDCs that decrease E2-2 expression produce less IFN and express costimulatory markers [15]. We identified a mechanism by which TNF $\alpha$ produced by monocytes attenuates E2-2 expression in pDCs. pDC dysfunction is attributed to the pathogenesis of several autoimmune diseases $[29,30]$ and has been observed in chronic HIV infection [28,31,32]. We provide novel insights in the regulation of pDCs which may be further used to promote or attenuate $\mathrm{pDC}$ function during disease progression.

\section{Materials and Methods}

\subsection{Preparation of $P B M C$}

This study was approved by the Institutional Review Board of New Jersey Medical School, ID Pro0119980237, approved November 14, 2019. Whole blood was collected from healthy, consenting adults in heparinized collection tubes. Peripheral blood mononuclear cells (PBMCs) were isolated using Lymphocyte Separation Medium (Corning, Manassas, VA, USA) via density centrifugation following the manufacturer's protocol. PBMCs were cultured in RPMI 1640 (VWR Life Science, Radnor, PA, USA) with L-glutamine (Corning) supplemented with $10 \%$ heat-inactivated fetal bovine serum (Gibco, Gaithersburg, MD, USA), $100 \mathrm{U} / \mathrm{mL}$ penicillin, $100 \mathrm{mg} / \mathrm{mL}$ streptomycin, $100 \mathrm{mg} / \mathrm{mL}$ gentamicin, and $5 \mathrm{mM}$ HEPES (Sigma Aldrich, St. Louis, MO, USA). Cell number was obtained using the Cellometer Auto 2000 (Nexcelom, Lawrence, MA, USA). 


\section{2. $p D C$ Enrichment \& Monocyte Depletion}

pDCs were enriched from PBMC, prepared as described above, by negative selection using the human plasmacytoid dendritic cell isolation kit-II (Miltenyi Biotec, Bergisch Gladbach, Germany) according to the manufacturer's instructions. Purity of resulting $\mathrm{pDC}$ population was assessed via flow cytometry as the proportion of BDCA2 CD123 double-positive cells, with purities ranging from $90-95 \%$. To confirm that negative selection excluded any contaminating $\mathrm{mDC}$ populations, purified $\mathrm{pDCs}$ were stained for CD11c, BDCA3, AXL, and Siglec6, which are known markers of human mDC [14]. Monocyte depletion was achieved using Miltenyi CD14 Microbeads according to the manufacturer's protocol. Depletion was verified by identifying CD14+ cells in control or monocyte-depleted PBMCs via flow cytometry.

\subsection{Viruses}

Herpes simplex virus type 1 (HSV) strain 2931 was originally obtained from Dr. C. Lopez, then at the Sloan-Kettering Institute (New York, NY, USA). HSV stocks were expanded in VERO cells (American Type Culture Collection, Manassas, VA, USA) and titered by a plaque assay on VERO cells. Influenza A virus (IAV) strain PR/8/34 propagated in specific-pathogen free eggs was purchased from Charles River Laboratory (SPAFAS, N. Franklin, CT, USA). HIV-MN strain was obtained from the AIDS and Cancer Virus Program (National Cancer Institute at the National Institutes of Health). All viruses were stored at $-80^{\circ} \mathrm{C}$ and thawed at room temperature before use.

\subsection{Antibodies}

PE/Cy7 anti-CD123 (6H6), allophycocyanin anti-CD123 (6H6), BV510 anti-CD123 (6H6), BV421 anti-BDCA2 (201A), PerCP Cy5.5 anti-BDCA2 (201A), allophycocyanin anti-CD3 (HIT3a), allophycocyanin/Cy7 anti-CD11c (Bu15), AF700 anti-CD14 (HCD14), PE/Cy7 anti-CD80 (2D10), PerCP Cy5.5 anti-CD86 (IT2.2), were purchased from BioLegend (San Diego, CA, USA). PE anti-IFN $\alpha$ (LT27:295) was purchased from Miltenyi Biotec (Bergisch Gladbach, Germany). PE anti-TLR4 (HTA125) was purchased from eBioscience (San Diego, CA, USA). PerCP anti-AXL (108724) and AF594 anti-Siglec 6 (767329) were purchased from R\&D Systems (Minneapolis, MN, USA). Unconjugated monoclonal anti-TCF4 (NCI-R159-6) was purchased from Abcam (Cambridge, MA, USA).

\subsection{Flow Cytometry}

PBMCs were surface stained and fixed with 2\% paraformaldehyde. Anti-TCF4 antibody was labeled with the AF488 Zenon Kit (ThermoFisher, Waltham, MA, USA) following the manufacturer's protocol. To stain for TCF-4, PBMCs and enriched pDCs were permeabilized using the previously published protocol [33]. Briefly, after surface staining, cells were fixed with $2 \%$ paraformaldehyde for $10 \mathrm{~min}$ and washed. After washing, $1 \mathrm{~mL} \mathrm{80 \%} \mathrm{methanol} \mathrm{was} \mathrm{slowly} \mathrm{added} \mathrm{to} \mathrm{each} \mathrm{sample.} \mathrm{Samples}$ were stored at -20 degrees overnight to allow for permeabilization. Cells were then washed and stained for E2-2. For detection of IFN $\alpha$, PBMCs were surface stained, fixed and permeabilized as described above or permeabilized using Triton X-100 (Sigma Aldrich). Samples were acquired at 300,000 events using an LSR-II or Fortessa X-20 (BD Biosciences, Franklin Lakes, NJ, USA). Flow cytometric analysis was performed with FlowJo software (FlowJo, LLC Ashland, OR, USA).

\subsection{Cell Culture}

PBMCs were cultured in $5 \mathrm{~mL}$ round-bottom polystyrene tubes at a concentration of $2 \times 10^{6} \mathrm{cells} / \mathrm{mL}$ in $10 \%$ FBS RPMI at $37^{\circ} \mathrm{C}$ with $5 \% \mathrm{CO}_{2} .1 \mathrm{~mL}$ of cell culture was used per sample. For analysis of purified pDC, $100,000 \mathrm{pDC}$ in $100 \mu \mathrm{L}$ of $10 \%$ FBS RPMI per sample were cultured in a round-bottom 96-well plate. PBMC were stimulated with a multiplicity of infection (MOI) of 1 of HSV-1 and IAV and purified pDCs were stimulated with an MOI of 10 (which yields a similar concentration of virus volume:volume as in the PBMCs). PBMCs were stimulated with $500 \mathrm{ng}$ p24 equivalents/mL of HIV-MN. 
$200 \mathrm{ng} / \mathrm{mL}$ of ultrapurified LPS (Invivogen, San Diego, CA, USA) and $5 \mathrm{ug} / \mathrm{mL}$ CpGA (ODN 2336) and CpGB (ODN 2006) (Invivogen) were used to stimulate both PBMCs and enriched pDCs. $10 \mu \mathrm{M}$ R848 (Resiquimod) was used to stimulate PBMCs (Invivogen). Supernatants were collected from PBMC cultures stimulated with LPS and kept at $-20{ }^{\circ} \mathrm{C}$ until use. pDCs and PBMCs stimulated with supernatant were cultured in media from autologous PBMCs. For inhibition of LPS binding by polymyxin B, supernatants were pre-treated with $1 \mu \mathrm{g} / \mathrm{mL}$ of polymyxin B (Invivogen) for a half hour before use. For cytokine stimulation, PBMCs were cultured with 10, 100, 1000, 5000, or 10,000 IU IFN $\alpha 2 \mathrm{~b}$ or $0.2,1,10 \mathrm{ng} / \mathrm{mL}$ of IL-10 or TNF $\alpha$ (PeproTech, Rocky Hill, NJ, USA).

\section{7. $q R T-P C R$}

Total RNA was isolated from PBMCs with the RNeasy Micro kit (Qiagen, Germantown, MD, USA) according to the manufacturer's protocol. Purity and concentration of RNA were measured with the nanodrop DeNovix FX11+ spectrophotometer/fluorometer (Wilmington, DE, USA). RNA was reverse transcribed to CDNA using random hexamers (Invivogen) and MuLV reverse transcriptase (Applied Biosystems, Foster City, CA, USA). cDNA was amplified via qPCR using a QuantStudio 3 to quantify mRNA expression in $\mathrm{pDC}$ relative to $\beta$-actin using the following Taqman gene-specific probe-based assays (Thermofisher): ACTB (Hs999999903_m1) and TCF4 (Hs00162613).

\subsection{Enzyme-Linked Immunosorbent Assay}

The presence of TNF $\alpha$ in supernatants was determined by enzyme-linked immunosorbent assays (ELISA). The Human TNF-alpha DuoSet ELISA kit from R\&D Systems was used following the manufacturer's protocol.

\subsection{Statistical Analysis}

Statistical tests were performed as repeated measures comparisons. Paired t-tests were used to calculate significant differences between two groups, rmANOVA with Dunnett's post hoc test to calculate significant differences between three or more groups, and two-way rmANOVA with Dunnett's post hoc test to calculate significant differences in experimental designs with multiple factors. All residuals were found to be normally distributed according to the Shapiro-Wilk test, and sphericity was assumed when applicable. Statistical tests were performed in GraphPad Prism 7 (San Diego, CA, USA). Data are presented as means \pm SEM. $p$ values $<0.05$ were considered significant. ${ }^{*} p<0.05$, ${ }^{* *} p<0.01,{ }^{* * *} p<0.001,{ }^{* * * *} p<0.0001$.

\section{Results}

\subsection{High E2-2 Expression Is Distinctive to $\mathrm{pDCs}$ and Is Downregulated after Stimulation}

It has previously been established that high expression of E2-2 is specific to unstimulated pDCs and there has been brief evidence that expression may be altered after activation. During chronic viral infection in both mice and humans, pDCs express significantly less E2-2 compared to healthy controls indicating that there may be a mechanism by which infection leads to diminished E2-2 expression $[19,27]$. To address if freshly-isolated human pDCs modify E2-2 expression after stimulation, we began by identifying peripheral pDCs that expressed E2-2. Flow cytometric analysis of E2-2 in freshly isolated primary human PBMCs verified that high E2-2 expression is restricted to pDCs (Figure 1A). Recent analysis of DC populations has revealed a subset of mDCs expressing CD123 that may fall into traditional CD123+ BDCA2+ pDC gates [8,14,34]. These AXL+Siglec 6+ mDCs produce less IFN than $\mathrm{pDCs}$ and can produce IL-12; they are also more efficient at stimulating $\mathrm{T}$ cell proliferation than traditional pDCs [14]. Since AXL+ Siglec6+ mDCs express $\mathrm{pDC}$ markers, it is possible that some of the attributes previously assigned to pDCs actually belong to AXL+Siglec $6+\mathrm{mDC}$, particularly the capacity to present antigen $[2,14]$. To prevent contamination of our $\mathrm{pDC}$ populations with AXL+ Siglec $6+$ DCs we used CD11c to exclude mDC populations and monocytes (Figure 1A). Additionally, we 
determined that negative-selection of $\mathrm{pDC}$ by magnetic activated cell sorting removed all AXL+ Siglec $6+$ cells from the cell culture (Figure 1B). CD11c+ cells expressed a low level of E2-2 and CD3+ T cells were E2-2 negative, in accordance with previous literature (Figure 1C). To investigate if stimulation of pDCs modulates E2-2 expression, PBMCs were treated with the TLR7 ligand R848 for $6 \mathrm{~h}$. Maximal IFN production in response to R848 occurs at $2 \mathrm{~h}$ [35], however, by this time there was no significant alterations in E2-2 protein levels. Continued stimulation of PBMCs lead to a significant decrease in E2-2 expression at $6 \mathrm{~h}$ (Figure 1D). We confirmed that diminished protein levels of E2-2 also corresponded with significantly downregulated mRNA expression (Figure 1E). mRNA levels were significantly lower by $2 \mathrm{~h}$ in the R848 treated samples indicated that E2-2 mRNA production is inhibited prior to a significant drop off in protein levels. This provides evidence that E2-2 expression can be altered during maturation of primary human pDCs.
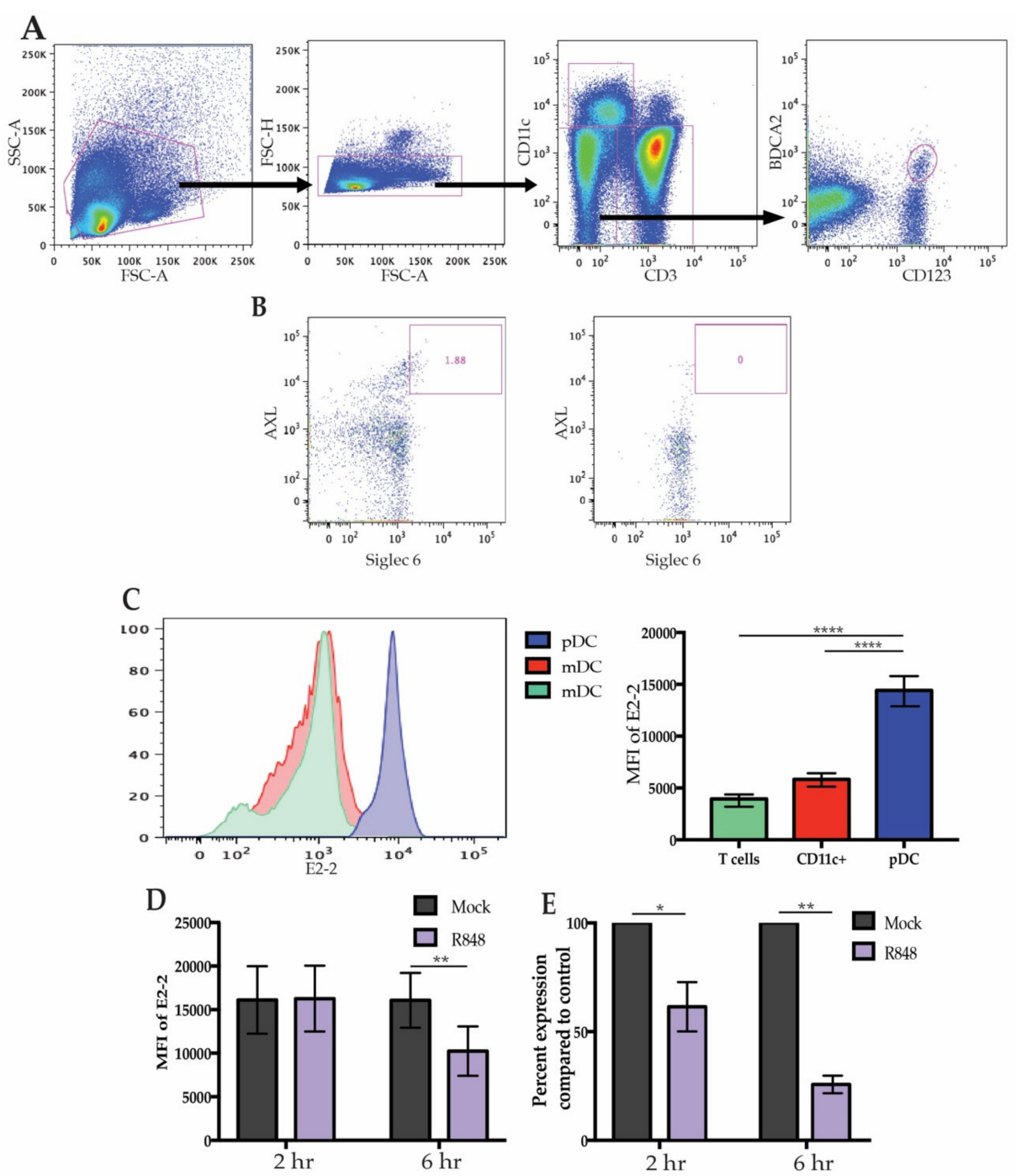

Figure 1. E2-2 expression in plasmacytoid dendritic cells (pDCs). (A) Gating strategy to identify pDCs from human peripheral blood mononuclear cells ( PBMCs). (B) Gating to determine removal of AXL+ Siglec 6+ DCs after negative selection for pDCs. (C) E2-2 expression in CD3+ and CD11c+ cells compared to $\mathrm{pDCs}$ as determine by flow cytometry. Representative histogram on the left, quantified mean fluorescent intensity (MFI) on the right. $n=11$ independent experiments. (D) PBMCs were stimulated with $10 \mu \mathrm{M}$ R848 for up to $6 \mathrm{~h}$ and E2-2 expression was measured via flow cytometry. $n=8$ independent experiments. (E) mRNA expression from PBMCs measured by qRT-PCR after $6 \mathrm{~h}$ R848 stimulation. $n=3$ independent experiments. Data are presented as means \pm SEM. $p$ values $<0.05$ were considered significant. ${ }^{*} p<0.05,{ }^{* *} p<0.01,{ }^{* * *} p<0.001,{ }^{* * *} p<0.0001$. 


\subsection{Differential Expression of E2-2 is Associated with Functional and Phenotypic Differences}

PBMCs treated with influenza A virus (IAV) and herpes simplex type 1 (HSV), which signal through TLR7 and TLR9, respectively, demonstrated a similar pattern of downregulation of E2-2, in which E2-2 was diminished after peak IFN response. By $12 \mathrm{~h}, \mathrm{E} 2-2$ expression in the pDC population was not significantly decreased in response to either IAV or HSV-1. However, at 18 h, E2-2 was significantly lower and stayed suppressed at $24 \mathrm{~h}$ (Figure 2A). Though there was a slight upward trend of E2-2 expression at $24 \mathrm{~h}$ during stimulation with IAV, there was not a significant increase in E2-2 expression. As with IAV, pDCs also respond to HIV-1 via TLR7 signaling [36] and HIV-1 stimulation also caused significant downregulation of E2-2 (Figure 2B). Optimal intracellular IFN $\alpha$ expression in response to viral stimulation in $\mathrm{pDCs}$ is seen $6-8 \mathrm{~h}[37,38]$ and upregulation of costimulatory markers occurs after IFN $\alpha$ production subsides. We verified this by stimulating PBMCs with IAV for $24 \mathrm{~h}$ and measured IFN $\alpha$ and CD86, a costimulatory molecule, expression every $6 \mathrm{~h}$. The percent of IFN $\alpha$ producing cells peaked at $6 \mathrm{~h}$ and rapidly declined over the next $18 \mathrm{~h}$ (Figure 2C). Conversely, CD86 was not significantly upregulated until $12 \mathrm{~h}$ (Figure 2C). These data support that downregulation of E2-2 occurs after pDCs have diminished production of IFN $\alpha$ and begun to upregulate costimulatory molecules required for $\mathrm{T}$ cell activation.

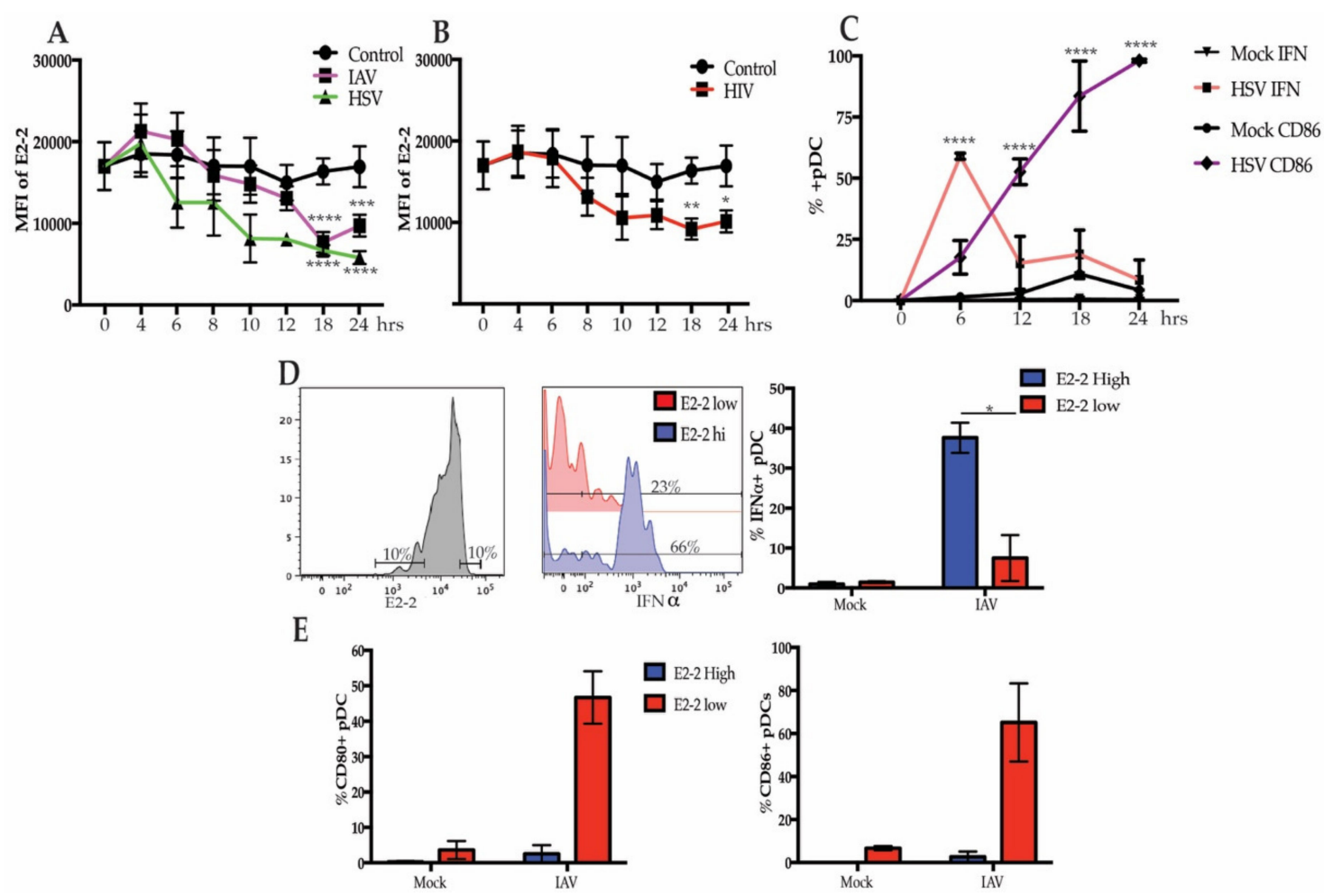

Figure 2. E2-2 expression after viral stimulation is associated with functional and phenotype differences. (A,B) Expression of E2-2 in pDCs after PBMCs were stimulated with herpes simplex virus type 1 (HSV) or influenza A virus (IAV) at a multiplicity of infection (MOI) of 1 (A) or $500 \mathrm{ng}$ p24 equivalents/mL of HIV-MN (B); $n=5$ independent experiments. (C) pDCs stimulated with HSV for 0-24 h were measured for intracellular IFN $\alpha$ and CD86 expression by flow cytometry, $n=3$ independent experiments. (D,E) Gating strategy to compare the 10\% highest and lowest E2-2 expressing pDCs after stimulation with IAV for $24 \mathrm{~h}$. Comparison of the percent IFN $\alpha+$ cells (D) and CD80+ and CD86+ (E). (D,E), $n=4$ independent experiments. Data are presented as means \pm SEM. $p$ values $<0.05$ were considered significant. ${ }^{*} p<0.05,{ }^{* *} p<0.01,{ }^{* * *} p<0.001,{ }^{* * * *} p<0.0001$.

In murine $\mathrm{pDCs}$ and human $\mathrm{pDC}$ cell lines, diminished E2-2 expression causes changes in phenotype and function marked by decreased IFN $\alpha$ expression and increased costimulatory markers [15]. Since pDC cell lines do not produce an equivalent concentration of IFN $\alpha$ compared to 
primary human pDCs and do not fully replicate primary pDC function [21-23], we interrogated these changes in our system. We stimulated PBMC with IAV for $24 \mathrm{~h}$, then stained and gated on the $10 \%$ of pDCs with the highest and lowest E2-2 expression and evaluated their intracellular IFN $\alpha$ production (Figure 2D). After stimulation with IAV, a greater percentage of E2-2 high pDCs were IFN $\alpha+$ compared to E2-2 low pDCs (Figure 2D). In contrast, E2-2 low pDCs upregulated the costimulatory markers CD80 and CD86 by $24 \mathrm{~h}$, while E2-2 high pDCs did not (Figure 2E). Together, these data suggest that E2-2 may be regulated in response to viral activation, and changes in E2-2 expression are associated with reduced IFN $\alpha$ production and upregulation of costimulatory markers.

\subsection{Decreased E2-2 Expression Is Not Induced by IFN $\alpha$ Receptor Signaling}

Production of IFN $\alpha$ by pDCs can result in an IFN $\alpha$ receptor (IFNAR)-mediated positive feedback loop [39]. To address the role of IFNAR signaling in E2-2 regulation, we utilized the differential effects of oligodeoxynucleotides CpGA and CpGB on pDCs. In human pDCs, CpGA induces robust IFN production leading to an autocrine IFN signaling loop. Conversely, CpGB induces a very low level of IFN production which is below the threshold required for autocrine signaling [39]. After $18 \mathrm{~h}$, PBMCs treated with either CpGA or CpGB decreased E2-2 (Figure 3A), arguing against an autocrine IFN $\alpha$ signaling loop for E2-2 downregulation.
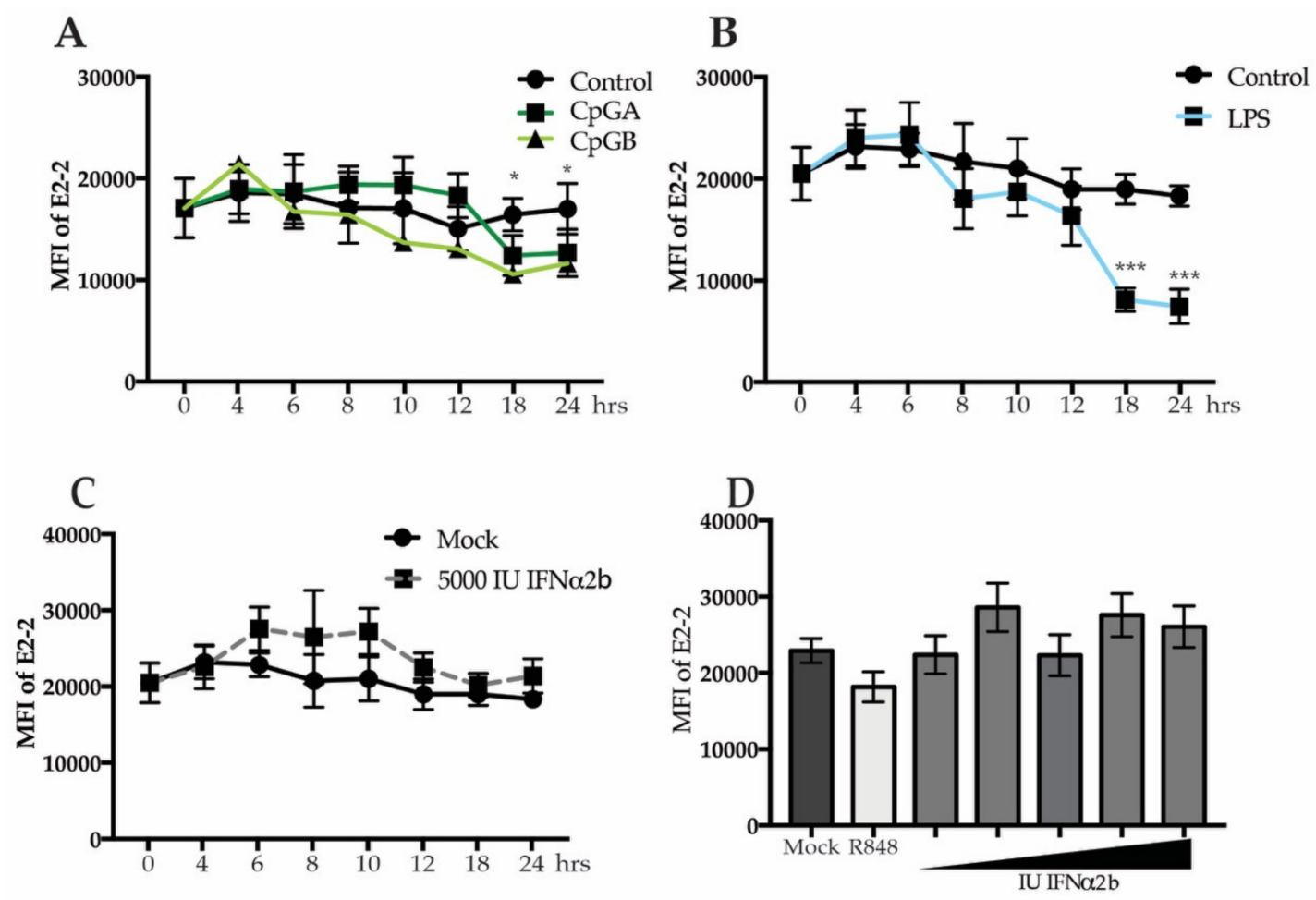

Figure 3. IFN $\alpha$ receptor signaling does not diminish E2-2 expression. PBMCs were treated with 5 $\mathrm{ug} / \mathrm{mL}$ of CpGA or CpGB (A), $200 \mathrm{ng} / \mathrm{mL}$ lipopolysaccharide (LPS), (B) or $5000 \mathrm{IU}$ recombinant IFN $\alpha 2 \mathrm{~b}$ (C) for up to $24 \mathrm{~h}$. (D) PBMCs were treated with 10, 100, 1000, 5000, or 10,000 IU of IFN $\alpha 2 \mathrm{~b}$ for $24 \mathrm{~h}$. $n=5$ independent experiments. Data are presented as means \pm SEM. $p$ values $<0.05$ were considered significant. ${ }^{*} p<0.05,{ }^{* *} p<0.01,{ }^{* * *} p<0.001$.

We previously reported that lipopolysaccharide (LPS) activates pDCs via TLR4 resulting in enhanced TLR4 and IRF7 expression via an NFKB-dependent pathway but with no IFN $\alpha$ production [7]. To determine if TLR4 signaling results in altered expression of E2-2 in the absence of IFN $\alpha$ production, we stimulated PBMCs with LPS and then measured E2-2 expression. By $18 \mathrm{~h}$, there was a significant reduction in E2-2 in LPS-treated PBMC (Figure 3B) that followed the same kinetics of E2-2 downregulation as cells stimulated with virus. To confirm that IFN $\alpha$ signaling does not play a 
role in E2-2 down-regulation in $\mathrm{pDC}$, we treated PBMCs with recombinant IFN $\alpha 2 \mathrm{~b}$ for up to $24 \mathrm{~h}$. There was no decrease in E2-2 expression at any of the time points, and, in fact, there was a small but not significant increase in E2-2 in the treated samples (Figure 3C). Furthermore, increasing concentrations of IFN $\alpha$ did not induce a change in E2-2 expression (Figure 3D). These data indicate that IFNAR signaling does not cause attenuated expression of E2-2.

\subsection{Secreted Cytokines from Neighboring Cells Lead to Downregulation of E2-2}

To determine if downregulation of E2-2 was due to direct sensing of TLR agonists by pDCs or in response to signals secreted by neighboring cells, we stimulated purified pDCs with TLR7, TLR9, and TLR4 agonists. pDCs were enriched to $>90 \%$ purity using negative selection and stimulated for $24 \mathrm{~h}$. After stimulation, there were no significant changes in E2-2 expression with HSV, CpGA, CpGB, or LPS in the purified pDCs (Figure 4A-C). Since we did not observe changes in purified pDCs, this suggests that the altered expression of E2-2 in PBMC cultures is not a direct effect. Other cells, such as monocytes and mDCs also produce a variety of cytokines in response to LPS and viruses [40] and it has previously been demonstrated that certain cytokines, including TNF $\alpha$ and IL-10 can alter pDC function [41-43]. Indeed, adding TNF $\alpha$ to the media before stimulation with HSV and IAV significantly decreased the total percent of IFN $\alpha+$ pDCs and the average amount of IFN produced by each cell, as determined by the intracellular mean fluorescent intensity (Figure 4D). The addition of IL-10 did not decrease the percent of IFN $\alpha+$ pDCs but did significantly diminish the mean fluorescent intensity (Figure 4D).
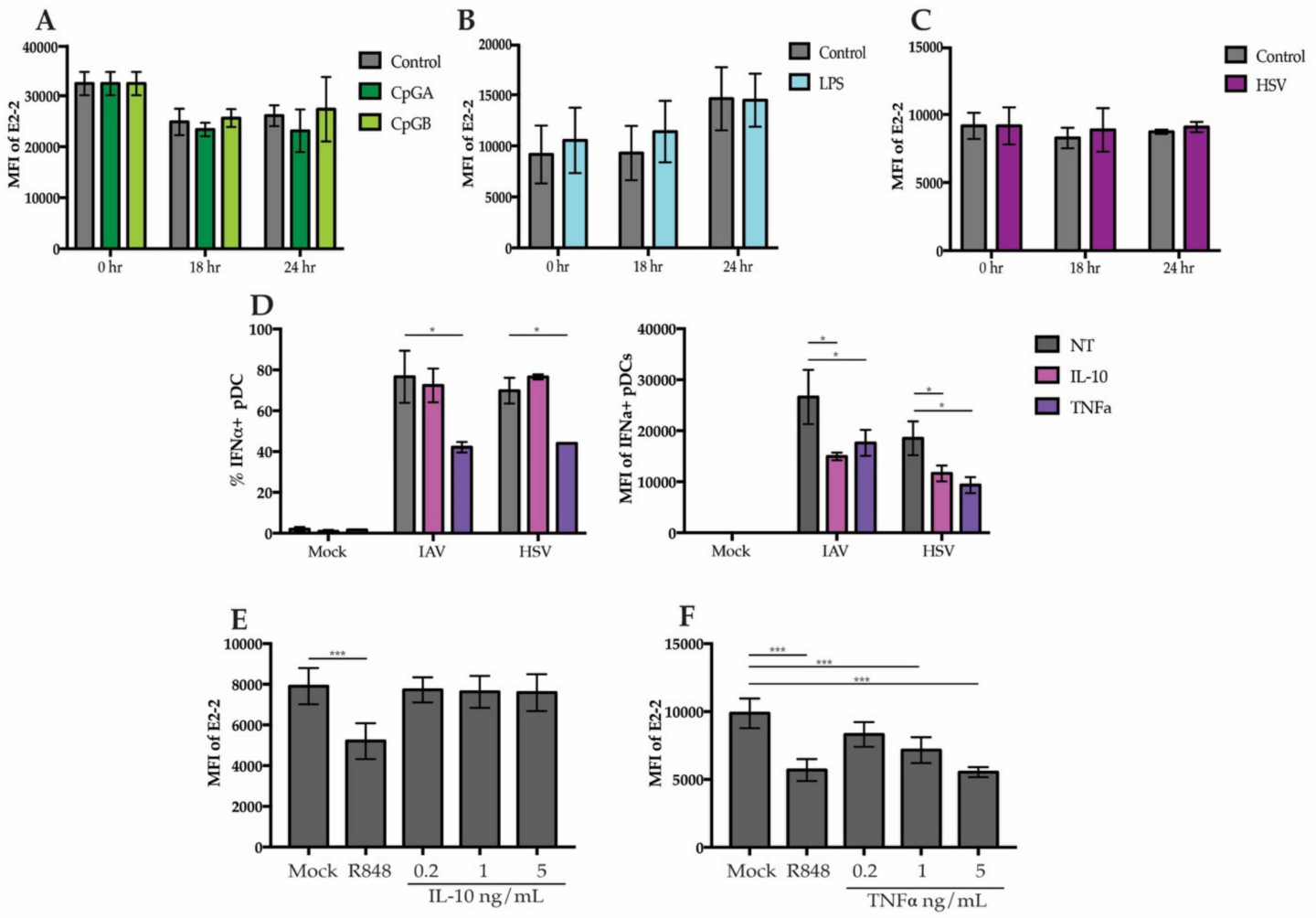

Figure 4. E2-2 expression is mediated by a pDC extrinsic signal (A-C) pDCs enriched to a purity $>90 \%$ were stimulated for 18 or $24 \mathrm{~h}$ with (A) $5 \mathrm{ug} / \mathrm{mL}$ CpGA or CpGB (B), $200 \mathrm{ng} / \mathrm{mL}$ LPS or (C), HSV. (D) PBMCs were cultured with $5 \mathrm{ng} / \mathrm{mL}$ of IL-10 or TNF $\alpha$ and stimulated with HSV or IAV. Intracellular IFN $\alpha$ production was measured at $6 \mathrm{~h}$. (E,F) PBMCs were treated with either $10 \mu \mathrm{M}$ R848, $0.2,1$, or $5 \mathrm{ng} / \mathrm{mL}$ IL-10 (E) or TNF $\alpha$ for $6 \mathrm{~h}$ then E2-2 expression was measured by flow cytometry. $n=3$ independent experiments. Data are presented as means \pm SEM. $p$ values $<0.05$ were considered significant. ${ }^{*} p<0.05,{ }^{* *} p<0.01,{ }^{* * *} p<0.001$. 
To determine whether the IL-10 and TNF $\alpha$ may be responsible for regulation of E2-2, we treated PBMCs with TNF $\alpha$ and IL-10. Treatment with IL-10 did not cause a decrease in E2-2 (Figure 4E). However, TNF $\alpha$ treatment alone was sufficient to decrease E2-2 expression by $6 \mathrm{~h}$ (Figure 4F). This reveals that a potential mechanism for TNF regulation of pDCs is through downregulation E2-2. resulting in Inhibition IFN Production.

\subsection{Regulation of E2-2 Is Mediated by TNF $\alpha$ Produced by Monocytes}

To determine if cytokines present in the supernatants of TLR-activated PBMCs are sufficient to induce downregulation of E2-2 in pDCs during stimulation, we cultured enriched pDCs with supernatants collected from PBMCs stimulated with LPS. These supernatants resulted in the downregulation of E2-2 (Figure 5A). To rule out the possibility that LPS in the supernatants was responsible for the downregulation of E2-2, supernatants were treated with polymyxin B, which prevents LPS binding to TLR4 and the activation of pDCs [7]. Downregulation of E2-2 did occur when supernatants were pretreated with polymyxin B (Figure $5 B$ ). To ensure that polymyxin B prevented LPS activating pDCs directly, we measured upregulation of TLR4 on pDCs. Stimulation with LPS and supernatant caused a significant increase in the percent of pDCs expressing TLR4. As we have previously reported [7], treatment with polymyxin B prevented upregulation of TLR4 (Figure 4F). These results indicate that E2-2 downregulation is not specific to TLR stimulation, but rather a response to the milieu of cytokines present in the media.
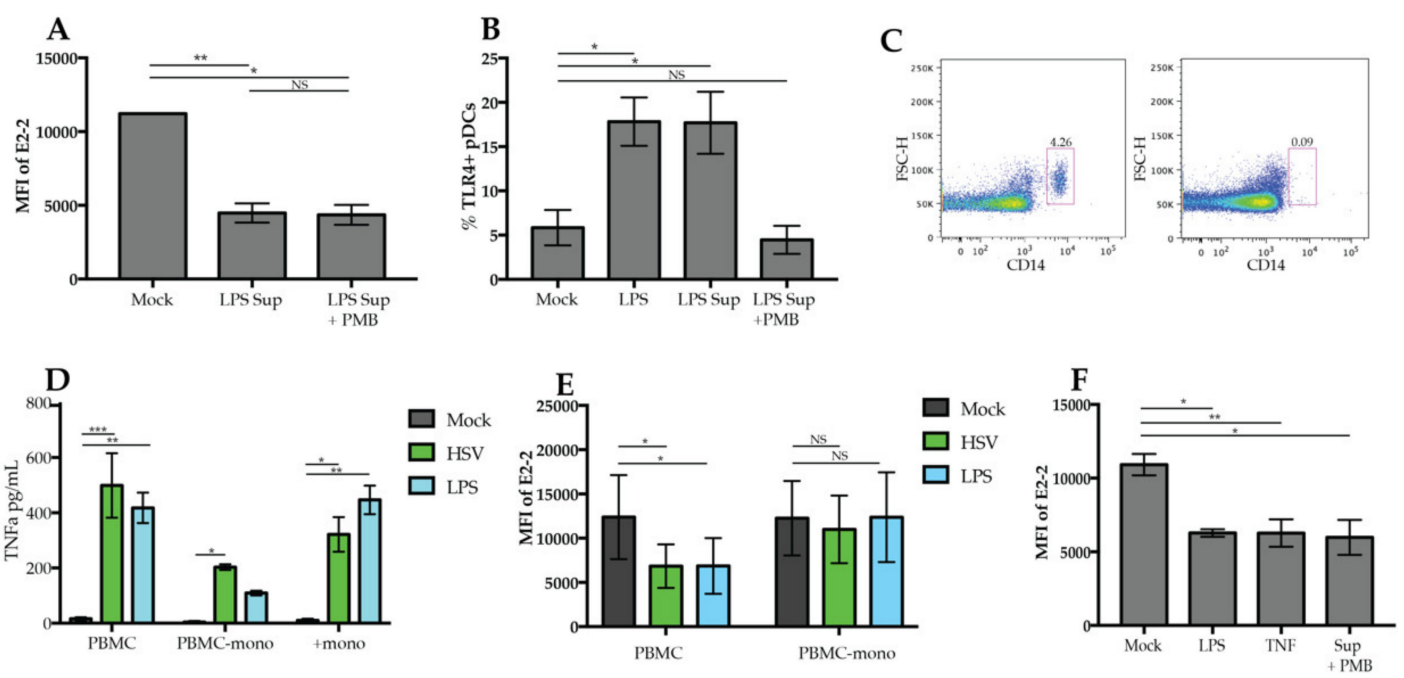

Figure 5. Monocyte-derived TNF $\alpha$ drives downregulation of E2-2. (A) Enriched pDCs were stimulated with $1 \mathrm{~mL}$ of supernatant from PBMCs stimulated with $200 \mathrm{ng} / \mathrm{mL}$ LPS for $24 \mathrm{~h}$ with or without the addition of polymyxin B (PMB) 30 min before the addition of LPS. (B) PBMCs were stimulated for $6 \mathrm{~h}$ with LPS, supernatant from PBMC stimulated with LPS or supernatant plus PMB, then TLR4 expression was quantified by flow cytometry (C) Monocytes were depleted from freshly isolated PBMCs. Depletion was confirmed via flow cytometry as indicated in the representative dot plot. (D) Supernatant collected from PBMCs, PBMCs depleted of monocytes (PBMC-mono), and positively-selected monocytes (+mono) stimulated with LPS for $24 \mathrm{~h}$ were measured for presence of TNF $\alpha$ by ELISA. (E) PBMCs or PBMC-mono cultures were cultured with either HSV or LPS for $24 \mathrm{~h}$ then E2-2 expression was measured. (F) $1 \mathrm{~mL}$ of supernatant from LPS-stimulated positively- selected monocyte cultures was used to culture PBMCs for $24 \mathrm{~h}$. Supernatant was pretreated with PMB for $30 \mathrm{~min}$ prior to culture to prevent the activation of PBMCs with LPS. $n=3$ independent experiments. Data are presented as means \pm SEM. $p$ values $<0.05$ were considered significant. ${ }^{*} p<0.05,{ }^{* *} p<0.01,{ }^{* * *} p<0.001,{ }^{* * * *} p<0.0001$.

Monocytes are a major source of $\mathrm{TNF} \alpha$, so to determine if they contribute to the regulation of E2-2, we depleted monocytes from PBMCs (PBMC-mono) (Figure 5C) and stimulated with HSV and LPS. In response to HSV, PBMC-mono cultures produced a significant amount of TNF relative to mock, 
however, it was drastically reduced compared to whole PBMC cultures (Figure 5D). Our lab and others have reported that $\mathrm{pDCs}$ produce $\mathrm{TNF} \alpha$ in response to viruses [44,45]; therefore, the TNF $\alpha$ production in PBMC-mono cultures may be a result of TNF $\alpha$ production by pDCs. Positively-selected monocytes cultured alone also produced a significant amount of TNF $\alpha$ after stimulation with HSV or LPS (Figure 5D) indicating that monocytes are a significant source of TNF $\alpha$ in PBMCs. When we stimulated PBMCs without the presence of monocytes, we found that there was no E2-2 downregulation in response to LPS or HSV (Figure 5E). Stimulation of PBMCs with supernatant collected from positively-selected monocytes did induce a significant reduction of E2-2 expression (Figure 5F). Therefore, these data support that the E2-2 downregulation we observed is due to monocytes producing TNF $\alpha$ that then triggers pDCs to alter E2-2 expression.

\section{Discussion}

Regulation of pDCs and their robust production of type I IFNs is pivotal in preventing aberrant inflammation $[29,30,46]$. While the production of type 1 IFNs is essential for both innate and adaptive immune responses, uncontrolled production can contribute to inflammatory disorders [46,47]. E2-2 is a master regulator of $\mathrm{pDC}$ function, promoting and repressing genes required for development of pDCs [9]. Since E2-2 expression is required for pDC maintenance, alterations in E2-2 can lead to a cell drastically changed in phenotype and function. In mice, inducible knockout of E2-2 gives rise to a cell that is markedly decreased in its ability to produce IFNs but more adapted to stimulate T cell responses [15]. This is recapitulated in human pDC cell lines where E2-2 knockdown decreases IFN production and increases the ability to induce $\mathrm{T}$ cell proliferation $[15,17]$, though $\mathrm{pDC}$ leukemic cells lines produce little or no IFN and do not fully represent primary human pDC function [20-23]. It has also been demonstrated that mouse and human pDCs downregulate E2-2 in response to chronic viral infection $[16,19]$. However, the signals leading to E2-2 modulation have not been elucidated.

High E2-2 expression is restricted to pDCs, with nominal expression in other DC subsets. During development, pDCs upregulate E2-2 while in the bone marrow before egressing into the blood [2]. We confirmed that primary human blood pDCs have much higher expression of E2-2 compared to other immune cells including $\mathrm{mDC}$ and $\mathrm{T}$ cells. We also demonstrated in $\mathrm{pDCs}$, peak intracellular IFN $\alpha$ occurs $6 \mathrm{~h}$ after the start of HSV and IAV stimulation and quickly diminishes [38]. Conversely, costimulatory markers are not significantly upregulated until $12 \mathrm{~h}$ and continue to increase in expression over time. We found that when stimulated, pDCs downregulated E2-2 during the process of costimulatory marker upregulation. During the time that E2-2 tapered, pDCs upregulated CD80 and CD86 and began to cease IFN production. These kinetics suggest that E2-2 may have a role in the upregulation of costimulatory markers during activation and in the moderation of IFN production.

Furthermore, we found that pDCs with lower E2-2 expression are more likely to have upregulated CD80 and CD86 compared to pDCs with high E2-2 expression and that the percent of pDCs producing IFN $\alpha$ was significantly greater in $\mathrm{pDC}$ s with high E2-2. These changes in function may represent the coordinated shift of $\mathrm{pDCs}$ from an interferon producing cell to antigen presenting cell. This transition is important to prevent overproduction of proinflammatory cytokines and for the activation of the adaptive immune system and may indicate that purified $\mathrm{pDC}$ populations are capable of stimulating $\mathrm{T}$ cells after they have downregulated E2-2.

IFN $\alpha$ receptor signaling in primary human pDCs results in a positive feedback loop and blocking the IFN $\alpha$ receptor decreases overall IFN production [39]. CpGB does not trigger a strong enough IFN response to lead to an IFN $\alpha$ feedback loop, however pDCs showed a similar extent of E2-2 downregulation in response to both CPGA and CpGB. Directly exposing cells to exogenous IFN $\alpha$ did not attenuate E2-2 protein expression, even at IFN concentrations vastly greater than physiological levels. There was even a small but not significant increase in E2-2 expression after exposure to IFN $\alpha$. Rather than suppressing, IFN may, instead, support continued expression of E2-2. Since viruses, CpGA, and CPGB caused diminished E2-2 expression, it does not appear that IFN $\alpha$ receptor signaling has a fundamental role in E2-2 downregulation during pDC maturation. 
In addition to TLR7 and TLR9, human pDCs also express TLR 4 [7,48]. Previous reports from our lab found that LPS activation of pDCs induces upregulation of IRF7 and TLR4. Stimulating pDCs with LPS prior to viral stimulus leads to a more robust IFN response which is mediated by the increased IRF7 expression [7]. This response led us to investigate if E2-2 expression has a role in pDCs response to LPS. We found that in PBMC cultures, E2-2 expression was repressed after stimulation with LPS. Following the pattern after viral stimulation, E2-2 was significantly decreased by $18 \mathrm{~h}$.

When we attempted to replicate our results from PBMCs in enriched pDC populations, we were unable to detect any alterations in E2-2 expression. It has been shown by our lab and others that pDC function can be altered by cytokines from neighboring cells [40,41,49]. TNF $\alpha$ and IL-10 have both been reported to inhibit IFN $\alpha$ production in $\mathrm{pDCs}$, however the mechanism leading to this inhibition is unclear [41,49]. Indeed, when we pretreated with IL-10 there was diminished mean fluorescent intensity of IFN $\alpha$ after viral stimulation. This indicates that, although the percent of $\mathrm{pDC}$ producing IFN remained the same, the amount of IFN produced on a per cell basis was attenuated. Adding TNF $\alpha$ to the media significantly inhibited both the percent IFN $\alpha+$ pDCs and the mean fluorescent intensity of IFN $\alpha$. To determine if IL-10 or TNF $\alpha$ alter E2-2 expression, we treated PBMCs with both cytokines and found that only TNF $\alpha$ was sufficient to induce downregulation of E2-2. Alteration of E2-2 expression in response to TNF $\alpha$ may represent a mechanism for the previously observed attenuation of pDC activation in response to TNF $\alpha$ [41].

To determine if there was a signal in the supernatant of PBMCs that caused downregulation of E2-2, we collected media from PBMCs stimulated with LPS and used this media to culture autologous pDCs. This resulted in significantly decreased E2-2. To ensure that LPS was not triggering signaling pDC through TLR4, we added PMB to the supernatant. PMB prevents binding of LPS to TLR4 and inhibits activation of pDCs with LPS [7]. In accordance with our previous observations, PMB prevented the upregulation of TLR4 in LPS treated pDCs. Taken together, these results show that the downregulation of E2-2 is not a direct effect but rather an indirect effect mediated by other cells in the PBMC population. Similar mediation of $\mathrm{pDC}$ activation and IFN production by TNF $\alpha$ has been described [40,41], but the molecular basis has not been well-defined.

Although PBMCs are a very heterogenous population comprised of many immune cell populations, we investigated the potential role of monocytes in E2-2 regulation because monocytes have been implicated in the regulation of pDCs [40,41,49]. Depleting monocytes from PBMCs diminished the concentration of TNF $\alpha$ in the supernatants; however, there was still a low level of TNF $\alpha$ present. This $\mathrm{TNF} \alpha$ may come from pDCs, which are known to produce TNF $\alpha$ in response to viral stimuli [44]. The concentration of TNF $\alpha$ in the monocyte depleted cultures was approximately half that of the PBMC cultures. This low concentration may not be enough to signal pDCs to downregulate E2-2. When PBMCs were stimulated in a monocyte-depleted PBMC culture, there was no altered expression of E2-2 in response to either LPS or HSV. Supernatants collected from purified monocyte cultures stimulated with LPS and HSV also induced downregulation of E2-2 in pDC. Together, these data show that TNF $\alpha$ produced by monocytes has a direct effect on the expression of E2-2 in pDCs.

Given that diminished E2-2 results in a greater capacity to stimulate T cells, altered E2-2 expression may assist in the development of a proficient antigen presenting $\mathrm{pDC}$. The concept that $\mathrm{pDC}$ shift from interferon producing cells to antigen presenting cells was suggested early in pDC research [50-54]. In 2003, the first direct evidence that pDCs present antigen and stimulate T cells was reported when Fonteneau et al. showed that pDCs exposed to IAV efficiently stimulated T cell proliferation, later reports also colloborate that $\mathrm{pDCs}$ can present antigen [52,55]. However, it has recently been debated if antigen presenting pDCs are instead an entirely distinct subset of AXL+ Siglec6+ mDCs [14,34]. Analysis of single-cell RNA sequencing and mass spectrometry of human PBMCs revealed these mDCs demonstrate characteristics of both $\mathrm{pDCs}$ and $\mathrm{mDC}$ s with low expression of E2-2 [8,14,34]. We have shown that $\mathrm{pDC}$ reduce E2-2 expression in response to stimulation with TNF $\alpha$; therefore, it is possible that some E2-2 low mDCs are pDCs that have encountered local or circulating TNF $\alpha$ and correspondingly downregulated E2-2. 
There are several reported circumstances in which pDC function is altered or inhibited in response to infection, cytokines, or cross-linking of surface markers. For example, pDCs are well known to be adversely affected by chronic HIV infection [28,31,32], and our previous work has shown that E2-2 expression is decreased in HIV-infected individuals [27]. It is possible that the loss-of-function observed in pDCs from people living with HIV may be caused by altered E2-2 expression. There are also other mechanisms that cause inhibition of pDC function such as cross-linking of BDCA2, CD123, and ILT7 [56-61]. However, if E2-2 has a role in inhibition in these contexts has not been confirmed. It would be intriguing to investigate if the attenuation observed after cross-linking or receptor binding is also mediated by E2-2. Conversely, it is plausible that pDCs from patients with interferonopathies may have deviant upregulation of E2-2 expression. By fully understanding the signals that regulate E2-2 and pDCs, we may be able to rescue function during chronic HIV infection and prevent over-activation of $\mathrm{pDC}$ in autoimmune disorders.

In conclusion, we have shown that $\mathrm{pDC}$ alter E2-2 expression in response to monocyte-derived $\mathrm{TNF} \alpha$. We propose a mechanism in which pDCs with high E2-2 expression initially produce IFN, but as monocytes begin to secrete TNF, pDCs downregulate E2-2. Attenuated E2-2 expression leads to decreased IFN production and upregulation of costimulatory markers. Ultimately, this contributes to a shift from a cell adept at IFN production to a cell equipped to present antigen, bridging the innate and adaptive compartments of the immune system.

Author Contributions: Conceptualization, methodology, and formal analysis of experiments was performed by H.K.D. and P.F.-B.; H.K.D. generated and analyzed experimental data and wrote the original manuscript draft; H.J.H. assisted with statistical analysis, analysis of experiments and edited the manuscript; P.F.-B. edited the manuscript, administered the project and acquired funding. All authors have read and agreed to the published version of the manuscript.

Funding: This research was funded by National Institute of Allergy and Infectious Diseases (T32 AI125185 and R01s AI106125 and AI026806 to PFB).

Conflicts of Interest: The authors declare no conflict of interest.

\section{References}

1. Fitzgerald-Bocarsly, P.; Dai, J.; Singh, S. Plasmacytoid dendritic cells and type i ifn: 50 years of convergent history. Cytokine Growth Factor Rev. 2008, 19, 3-19. [CrossRef]

2. Reizis, B. Plasmacytoid dendritic cells: Development, regulation, and function. Immunity 2019, 50, 37-50. [CrossRef]

3. Fitzgerald-Bocarsly, P. Human natural interferon-alpha producing cells. Pharmac. Ther. 1993, 60, $39-63$. [CrossRef]

4. Swiecki, M.; Colonna, M. The multifaceted biology of plasmacytoid dendritic cells. Nat. Rev. Immunol. 2015, 15, 471-485. [CrossRef] [PubMed]

5. Fitzgerald-Bocarsly, P.; Feng, D. The role of type I interferon production by dendritic cells in host defense. Biochimie 2007, 89, 843-855. [CrossRef] [PubMed]

6. Guiducci, C.; Coffman, R.L.; Barrat, F.J. Signalling pathways leading to ifn-alpha production in human plasmacytoid dendritic cell and the possible use of agonists or antagonists of TLR7 and TLR9 in clinical indications. J. Intern. Med. 2009, 265, 43-57. [CrossRef] [PubMed]

7. Dai, J.; Megjugorac, N.J.; Amrute, S.B.; Fitzgerald-Bocarsly, P. Regulation of IFN regulatory factor-7 and IFN-a production by enveloped virus and lipopolysaccharide in human plasmacytoid dendritic cells. J. Immunol. 2004, 173, 1535-1548. [CrossRef]

8. See, P.; Dutertre, C.A.; Chen, J.; Gunther, P.; McGovern, N.; Irac, S.E.; Gunawan, M.; Beyer, M.; Handler, K.; Duan, K.; et al. Mapping the human DC lineage through the integration of high-dimensional techniques. Science 2017, 356, eaag3009. [CrossRef]

9. Reizis, B.; Bunin, A.; Ghosh, H.S.; Lewis, K.L.; Sisirak, V. Plasmacytoid dendritic cells: Recent progress and open questions. Annu Rev. Immunol. 2011, 29, 163-183. [CrossRef] 
10. Nagasawa, M.; Schmidlin, H.; Hazekamp, M.G.; Schotte, R.; Blom, B. Development of human plasmacytoid dendritic cells depends on the combined action of the basic helix-loop-helix factor E2-2 and the ETS factor Spi-b. Eur. J. Immunol. 2008, 38, 2389-2400. [CrossRef]

11. Li, H.S.; Yang, C.Y.; Nallaparaju, K.C.; Zhang, H.; Liu, Y.J.; Goldrath, A.W.; Watowich, S.S. The signal transducers STAT5 and STAT3 control expression of ID2 and E2-2 during dendritic cell development. Blood 2012, 120, 4363-4373. [CrossRef]

12. Mastio, J.; Simand, C.; Cova, G.; Kastner, P.; Chan, S.; Kirstetter, P. Ikaros cooperates with notch activation and antagonizes TGFbeta signaling to promote pDC development. PLoS Genet. 2018, 14, e1007485. [CrossRef]

13. Allman, D.; Dalod, M.; Asselin-Paturel, C.; Delale, T.; Robbins, S.H.; Trinchieri, G.; Biron, C.A.; Kastner, P.; Chan, S. Ikaros is required for plasmacytoid dendritic cell differentiation. Blood 2006, 108, 4025-4034. [CrossRef] [PubMed]

14. Villani, A.; Satija, R.; Reynolds, G.; Sarkizova, S.; Shekhar, K.; Fletcher, J.; Griesbeck, M.; Butler, A.; Zheng, S.; Lazo, S.; et al. Single-cell RNA-seq reveals new types of human blood dendritic cells, monocytes, and progenitors. Science 2017, 356, eaah4573. [CrossRef] [PubMed]

15. Ghosh, H.S.; Cisse, B.; Bunin, A.; Lewis, K.L.; Reizis, B. Continuous expression of the transcription factor e2-2 maintains the cell fate of mature plasmacytoid dendritic cells. Immunity 2010, 33, 905-916. [CrossRef] [PubMed]

16. Cisse, B.; Caton, M.L.; Lehner, M.; Maeda, T.; Scheu, S.; Locksley, R.; Holmberg, D.; Zweier, C.; den Hollander, N.S. Transcription factor E2-2 is an essential and specific regulator of plasmacytoid dendritic cell development. Cell 2008, 135, 37-48. [CrossRef] [PubMed]

17. Cheng, M.; Zhang, X.; Yu, H.; Du, P.; Plumas, J.; Chaperot, L.; Su, L.; Zhang, L. Characterization of species-specific genes regulated by E2-2 in human plasmacytoid dendritic cells. Sci. Rep. 2015, 5, 10752. [CrossRef]

18. Grajkowska, L.T.; Ceribelli, M.; Lau, C.M.; Warren, M.E.; Tiniakou, I.; Nakandakari Higa, S.; Bunin, A.; Haecker, H.; Mirny, L.A.; Staudt, L.M.; et al. Isoform-specific expression and feedback regulation of E protein TCF4 control dendritic cell lineage specification. Immunity 2017, 46, 65-77. [CrossRef]

19. Belnoue, E.; Fontannaz, P.; Rochat, A.; Tougne, C.; Bergthaler, A.; Lambert, P.; Pinschewer, D.D.; Siegrist, C. Functional limitations of plasmacytoid dendritic cells limit type I interferon, $\mathrm{T}$ cell responses and virus control in early life. PLoS ONE 2013, 8, 1-12. [CrossRef]

20. Carmona-Sáez, P.; Varela, N.; Luque, M.J.; Toro-Domínguez, D.; Martorell-Marugan, J.; Alarcóln-Riquelme, M.E.; Marañón, C.; Berger, B. Metagene projection characterizes Gen2.2 and Cal-1 as relevant human plasmacytoid dendritic cell models. Bioinformatics 2017, 33, 3691-3695. [CrossRef]

21. Maeda, T.; Murata, K.; Fukushima, T.; Sugahara, K.; Tsuruda, K.; Anami, M.; Onimaru, Y.; Tsukasaki, K.; Tomonaga, M.; Moriuchi, R.; et al. A novel plasmacytoid dendritic cell line, Cal-1, established from a patient with blastic natural killer cell lymphoma. Int. J. Hematol. 2005, 81, 148-154. [CrossRef] [PubMed]

22. Chaperot, L.; Blum, A.; Manches, O.; Lui, G.; Angel, J.; Molens, J.P.; Plumas, J. Virus or TLR agonists induce trail-mediated cytotoxic activity of plasmacytoid dendritic cells. J. Immunol. 2006, 176, 248-255. [CrossRef]

23. Narita, M.; Watanabe, N.; Yamahira, A.; Hashimoto, S.; Tochiki, N.; Saitoh, A.; Kaji, M.; Nakamura, T.; Furukawa, T.; Toba, K.; et al. A leukemic plasmacytoid dendritic cell line, PMDC05, with the ability to secrete IFN-alpha by stimulation via toll-like receptors and present antigens to naive T cells. Leuk. Res. 2009, 33, 1224-1232. [CrossRef] [PubMed]

24. Bar-On, L.; Birnberg, T.; Lewis, K.L.; Edelson, B.T.; Bruder, D.; Hildner, K.; Buer, J.; Murphy, K.M.; Reizis, B.; Jung, S. CX3CR1+ CD8alpha+ dendritic cells are a steady-state population related to plasmacytoid dendritic cells. Proc. Natl. Acad. Sci. USA 2010, 107, 14745-14750. [CrossRef] [PubMed]

25. Lindstedt, M.; Lundberg, K.; Borrebaeck, C.A.K. Gene family clustering identifies functionally associated subsets of human in vivo blood and tonsillar dendritic cells. J. Immunol. 2005, 175, 4839-4846. [CrossRef] [PubMed]

26. Li, H.S.; Gelbard, A.; Martinez, G.J.; Esashi, E.; Zhang, H.; Nguyen-Jackson, H.; Liu, Y.J.; Overwijk, W.W.; Watowich, S.S. Cell-intrinsic role for IFN-alpha-STAT1 signals in regulating murine peyer patch plasmacytoid dendritic cells and conditioning an inflammatory response. Blood 2011, 118, 3879-3889. [CrossRef] [PubMed]

27. Macal, M.; Jo, Y.; Dallari, S.; Chang, A.Y.; Dai, J.; Swaminathan, S.; Wehrens, E.J.; Fitzgerald-Bocarsly, P.; Zúñiga, E.I. Self-renewal and toll-like receptor signaling sustain exhausted plasmacytoid dendritic cells during chronic viral infection. Immunity 2018, 48, 730-744. [CrossRef] 
28. Fitzgerald-Bocarsly, P.; Jacobs, E.S. Plasmacytoid dendritic cells in hiv infection: Striking a delicate balance. J. Leukoc. Biol. 2010, 87, 609-620. [CrossRef]

29. Di Domizio, J.; Cao, W. Fueling autoimmunity: Type I interferon in autoimmune diseases. Expert Rev. Clin. Immunol. 2013, 9, 201-210. [CrossRef]

30. Sozzani, S.; Del Prete, A.; Bosisio, D. Dendritic cell recruitment and activation in autoimmunity. J. Autoimmun. 2017, 85, 126-140. [CrossRef]

31. Feldman, S.; Stein, D.; Amrute, S.; Denny, T.; Garcia, Z.; Kloser, P.; Sun, Y.; Megjugorac, N.; Fitzgerald-Bocarsly, P. Decreased interferon-a production in HIV-infected patients correlates with numerical and functional deficiencies in circulating type 2 dendritic cell precursors. Clin. Immunol. 2001, 101, 201-210. [CrossRef] [PubMed]

32. O’Brien, M.; Manches, O.; Bhardwaj, N. Plasmacytoid dendritic cells in HIV infection. Adv. Exp. Med. Biol. 2013, 762, 71-107. [CrossRef] [PubMed]

33. Ceribelli, M.; Hou, Z.E.; Kelly, P.N.; Huang, D.W.; Wright, G.; Ganapathi, K.; Evbuomwan, M.O.; Pittaluga, S.; Shaffer, A.L.; Marcucci, G.; et al. A druggable TCF4- and Brd4-dependent transcriptional network sustains malignancy in blastic plasmacytoid dendritic cell neoplasm. Cancer Cell 2016, 30, 764-778. [CrossRef] [PubMed]

34. Alcantara-Hernandez, M.; Leylek, R.; Wagar, L.E.; Engleman, E.G.; Keler, T.; Marinkovich, M.P.; Davis, M.M.; Nolan, G.P.; Idoyaga, J. High-dimensional phenotypic mapping of human dendritic cells reveals interindividual cariation and tissue specialization. Immunity 2017, 47, 1037-1050. [CrossRef] [PubMed]

35. Gibson, S.J.; Lindh, J.M.; Riter, T.R.; Gleason, R.M.; Rogers, L.M.; Fuller, A.E.; Oesterich, J.L.; Gorden, K.B.; Qiu, X.; McKane, S.W.; et al. Plasmacytoid dendritic cells produce cytokines and mature in response to the TLR7 agonists, imiquimod and resiquimod. Cell Immunol. 2002, 218, 74-86. [CrossRef]

36. Beignon, A.S.; McKenna, K.; Skoberne, M.; Manches, O.; DaSilva, I.; Kavanagh, D.G.; Larsson, M.; Gorelick, R.J.; Lifson, J.D.; Bhardwaj, N. Endocytosis of HIV-1 activates plasmacytoid dendritic cells via toll-like receptor-viral RNA interactions. J. Clin. Invest. 2005, 115, 3265-3275. [CrossRef]

37. Di Domizio, J.; Blum, A.; Gallagher-Gambarelli, M.; Molens, J.; Chaperot, L.; Plumas, J. Tlr7 stimulation in human plasmacytoid dendritic cells leads to the induction of early IFN-inducible genes in the absence of type I IFN. Blood 2009, 114, 1794-1802. [CrossRef]

38. Coccia, E.M.; Severa, M.; Giacomini, E.; Monneron, D.; Remoli, M.E.; Julkunen, I.; Cella, M.; Lande, R.; Uze, G. Viral infection and toll-like receptor agonists induce a differential expression of type I and lambda interferons in human plasmacytoid and monocyte-derived dendritic cells. Eur. J. Immunol. 2004, 34, 796-805. [CrossRef]

39. Kerkmann, M.; Rothenfusser, S.; Hornung, V.; Towarowski, A.; Wagner, M.; Sarris, A.; Giese, T.; Endres, S.; Hartmann, G. Activation with CpG-a and CpG-b oligonucleotides reveals two distinct regulatory pathways of type I IFN synthesis in human plasmacytoid dendritic cells. J. Immunol. 2003, 170, 4465-4474. [CrossRef]

40. Kornbluth, R.S.; Edgington, T.S. Tumor necrosis factor production by human monocytes is a regulated event: Induction of TNF-alpha-mediated cellular cytotoxicity by endotoxin. J. Immunol. 1986, 137, 2585-2591.

41. Shi, B.; Ren, G.; Hu, Y.; Wang, S.; Zhang, Z.; Yuan, Z. Hbsag inhibits IFN-a production in plasmacytoid dendritic cells through TNF-a and IL-10 induction in monocytes. PLoS ONE 2012, 7, 1-11. [CrossRef] [PubMed]

42. Gupta, M.; Mahanty, S.; Ahmed, R.; Rollin, P.E. Monocyte-derived human macrophages and peripheral blood mononuclear cells infected with ebola virus secrete mip- $1 \alpha$ and TNF- $\alpha$ and inhibit poly-ic-induced ifn- $\alpha$ in vitro. Virology 2001, 284, 20-25. [CrossRef] [PubMed]

43. Payvandi, F.; Amrute, S.; Fitzgerald-Bocarsly, P. Exogenous and endogenous IL-10 regulate IFN- $\alpha$ production by peripheral blood mononuclear cells in response to viral stimulation. J. Immunol. 1998, 160, 5861-5868. [PubMed]

44. Megjugorac, N.J.; Young, H.A.; Amrute, S.B.; Olshalsky, S.L.; Fitzgerald-Bocarsly, P. Virally stimulated plasmacytoid dendritic cells produce chemokines and induce migration of T and NK cells. J. Leukoc. Biol. 2004, 75, 504-514. [CrossRef] [PubMed]

45. Alculumbre, S.G.; Saint-Andre, V.; Di Domizio, J.; Vargas, P.; Sirven, P.; Bost, P.; Maurin, M.; Maiuri, P.; Wery, M.; Roman, M.S.; et al. Diversification of human plasmacytoid predendritic cells in response to a single stimulus. Nat. Immunol. 2018, 19, 63-75. [CrossRef] [PubMed]

46. Saadeh, D.; Kurban, M.; Abbas, O. Update on the role of plasmacytoid dendritic cells in inflammatory/autoimmune skin diseases. Exp. Dermatol. 2016, 25, 415-421. [CrossRef] [PubMed] 
47. Picard, C.; Belot, A. Does type-I interferon drive systemic autoimmunity? Autoimmun. Rev. 2017, 16, 897-902. [CrossRef]

48. Raieli, S.; Trichot, C.; Korniotis, S.; Pattarini, L.; Soumelis, V. TLR1/2 orchestrate human plasmacytoid pre-dendritic cell response to gram+ bacteria. PLoS Biol. 2019, 17. [CrossRef]

49. Pierog, P.L.; Zhao, Y.; Singh, S.; Dai, J.; Yap, G.S.; Fitzgerald-Bocarsly, P. Toxoplasma gondii inactivates human plasmacytoid dendritic cells by functional mimicry of IL-10. J. Immunol. 2018, 200, 186-195. [CrossRef]

50. Soumelis, V.; Liu, Y.J. From plasmacytoid to dendritic cell: Morphological and functional switches during plasmacytoid pre-dendritic cell differentiation. Eur. J. Immunol. 2006, 36, 2286-2292. [CrossRef]

51. Salio, M.; Palmowski, M.J.; Atzberger, A.; Hermans, I.F.; Cerundolo, V. CpG-matured murine plasmacytoid dendritic cells are capable of in vivo priming of functional CD8 $\mathrm{T}$ cell responses to endogenous but not exogenous antigens. J. Exp. Med. 2004, 199, 567-579. [CrossRef] [PubMed]

52. Fonteneau, J.F.; Gilliet, M.; Larsson, M.; Dasilva, I.; Munz, C.; Liu, Y.J.; Bhardwaj, N. Activation of influenza virus-specific CD4+ and CD8+ T cells: A new role for plasmacytoid dendritic cells in adaptive immunity. Blood 2003, 101, 3520-3526. [CrossRef] [PubMed]

53. Grouard, G.; Rissoan, M.C.; Filgueira, L.; Durand, I.; Banchereau, J.; Liu, Y.J. The enigmatic plasmacytoid T cells develop into dendritic cells with interleukin (IL)-3 and CD40-ligand. J. Exp. Med. 1997, 185, 1101-1112. [CrossRef] [PubMed]

54. Zuniga, E.I.; McGavern, D.B.; Pruneda-Paz, J.L.; Teng, C.; Oldstone, M.B.A. Bone marrow plasmacytoid dendritic cells can differentiate into myeloid dendritic cells upon virus infection. Nat. Immunol. 2004, 5, 1227-1234. [CrossRef]

55. Hoeffel, G.; Ripoche, A.C.; Matheoud, D.; Nascimbeni, M.; Escriou, N.; Lebon, P.; Heshmati, F.; Guillet, J.G.; Gannage, M.; Caillat-Zucman, S.; et al. Antigen crosspresentation by human plasmacytoid dendritic cells. Immunity 2007, 27, 481-492. [CrossRef]

56. Fanning, S.L.; George, T.C.; Feng, D.; Feldman, S.B.; Megjugorac, N.J.; Izaguirre, A.G.; Fitzgerald-Bocarsly, P. Receptor cross-linking on human plasmacytoid dendritic cells leads to the regulation of IFN- $\alpha$ production. J. Immunol. 2006, 177, 5829-5839. [CrossRef]

57. Riboldi, E.; Daniele, R.; Cassatella, M.A.; Sozzani, S.; Bosisio, D. Engagement of BDCA-2 blocks trail-mediated cytotoxic activity of plasmacytoid dendritic cells. Immunobiology 2009, 214, 868-876. [CrossRef]

58. Dzionek, A.; Sohma, Y.; Nagafune, J.; Cella, M.; Colonna, M.; Facchetti, F.; Gunther, G.; Johnston, I.; Lanzavecchia, A.; Nagasaka, T.; et al. BDCA-2, a novel plasmacytoid dendritic cell-specific type II c-type lectin, mediates antigen capture and is a potent inhibitor of interferon alpha/beta induction. J. Exp. Med. 2001, 194, 1823-1834. [CrossRef]

59. Cao, W.; Bover, L.; Cho, M.; Wen, X.; Hanabuchi, S.; Bao, M.; Rosen, D.B.; Wang, Y.H.; Shaw, J.L.; Du, Q.; et al. Regulation of TLR7/9 responses in plasmacytoid dendritic cells by Bst2 and ILT7 receptor interaction. J. Exp. Med. 2009, 206, 1603-1614. [CrossRef]

60. Cho, M.; Ishida, K.; Chen, J.; Ohkawa, J.; Chen, W.; Namiki, S.; Kotaki, A.; Arai, N.; Arai, K.; Kamogawa-Schifter, Y. Sage library screening reveals ILT7 as a specific plasmacytoid dendritic cell marker that regulates type Ii IFN production. Int. Immunol. 2008, 20, 155-164. [CrossRef]

61. Cao, W.; Rosen, D.B.; Ito, T.; Bover, L.; Bao, M.; Watanabe, G.; Yao, Z.; Zhang, L.; Lanier, L.L.; Liu, Y.J. Plasmacytoid dendritic cell-specific receptor ILT7-fc epsilonri gamma inhibits toll-like receptor-induced interferon production. J. Exp. Med. 2006, 203, 1399-1405. [CrossRef] [PubMed]

(C) 2020 by the authors. Licensee MDPI, Basel, Switzerland. This article is an open access article distributed under the terms and conditions of the Creative Commons Attribution (CC BY) license (http://creativecommons.org/licenses/by/4.0/). 